\title{
ХРОМШПИНЕЛИДЫ АЛМАЗНОЙ АССОЦИАЦИИ НА СЕВЕРНОМ СКЛОНЕ ВОРОНЕЖСКОЙ АНТЕКЛИЗЫ
}

\author{
А. В. Черешинский \\ Воронежский государственный университет \\ Поступила в редакцию 7 мая 2018 г.
}

\begin{abstract}
Аннотация: в статье приведены данные о минералах-индикаторах кимберлитов из меловых отложений северного склона Воронежской антеклизы. Образования аптского яруса на рассмотренной территории содержат рекордное количество хромшпинелидов, до 1784 знаков на пробу объемом 20 литров. Выделенные хромшпинелиды характеризуются повышенным содержанием $\mathrm{Cr}_{2} \mathrm{O}_{3}$, около $32 \%$ проанализированных зерен на диаграмме Н.В. Соболева попадают в область алмазной ассочиачии. Даны морфологические описания хромшпинелидов, выделены зерна «мантийного» типа, характерные для кимберлитов. Установлен источник сноса этих минералов, который расположен юго-восточнее изученной площзади.
\end{abstract}

Ключевые слова: Воронежская антеклиза, минераль-индикаторы кимберлитов, хромшпинелид, мезозой.

\section{FINDINGS CHROME-SPINELLIDES DIAMOND ASSOCIATION ON THE NORTHERN SLOPE OF THE VORONEZH ANTECLINE}

\begin{abstract}
: the article presents data on the indicator minerals of kimberlites of cretaceous sediments of the northern slope of the Voronezh antecline. Aptian deposits in the study area contain a record amount of chrome-spinellides, up to 1784 grains per sample in volume of 20 liters. Chrome-spinellids are characterized by a high content of $\mathrm{Cr}_{2} \mathrm{O}_{3}$, about $32 \%$ of the analysed grains in the diagram of N.V. Sobolev fall into the diamond association. The morphological descriptions of chrome-spinellides are expounded, the highlighted grains of "mantle" type are characteristic for kimberlites. The primary source of these minerals is located to the southeast of the study area.
\end{abstract}

Keywords: Voronezh anteclyse, indicator minerals of kimberlites, chrome-spinellids, mesozoic.

Шлихоминералогический метод является одним из основных при поиске и прогнозировании алмазных месторождений, с его помощью открыто большое количество кимберлитовых и лампроитовых трубок как у нас в стране, так и за ее пределами [1-3]. В настоящее время метод не потерял своей актуальности и является одним из наиболее результативных [4]. Исследование морфологических особенностей минералов-индикаторов кимберлитов (МИК) и их химического состава позволяет проводить генетическую интерпретацию, устанавливать первичные источники сноса и прогнозировать алмазоносность исследуемой территории $[5,6]$.

В пределах Воронежской антеклизы (ВА) МИК выделены в различных по возрасту промежуточных коллекторах. Установлено более 100 разрезов, содержащих мелкие кристаллы алмазов, хромшпинелидов, пиропов, пикроильменитов и хромдиопсидов, однако, большинство местонахождений характеризуется низким и умеренным содержанием МИК [7-9]. Наиболее хорошо опробованными являются образования мезозоя, это объясняется широкой доступностью этих пород и распространением в них терригенных грубозер- нистых разностей, благоприятных для концентрации индикаторных минералов [10].

Для наиболее древних отложений мезозоя (батский, келловейский, готеривский и барремский ярусы) характерны единичные кристаллы мелких алмазов и единичные зерна МИК. Породы аптского и альбского ярусов являются самыми продуктивными, здесь отмечаются многочисленные находки мелких алмазов, хромшпинелидов, пиропов и пикроильменитов. Мелкие алмазы выделены из 8 местонахождений, 5 из них имеют аптский возраст, 3 альбский. На северном склоне ВА из альбских песков выделено большое количество высокобарических минералов, максимальные содержания - 158 зерен пиропов, 344 знака хромшпинелидов (на пробу объемом $1 \mathrm{~m}^{3}$ ) [8]. Количество МИК в остальных пробах не превышает первые десятки знаков. Исключением являются местонахождения, выделенные при проведении работ по ГДП-200 листа N-37-XXXIII (Елец). Количество хромшпинелидов в разрезах на этой площади составляет несколько тысяч зерен на пробу объемом 20 литров.

Сеноманский коллектор содержит индикаторные минералы в существенно меньшем количестве, по 
сравнению с нижнемеловыми разрезами. При изучении Центральной титан-циркониевой россыпи (Тамбовская область), было выделено 17 зерен мелких алмазов [11]. Значимые находки МИК сделаны в пяти пунктах, в пределах Воронежской области, количество хромшпинелидов и пиропов в пробах незначительно (не более 7 зерен).

При проведении геологосъемочных и поисковых работ на северном склоне ВА (площадь листа М-37III (Касторное)) особенное внимание при шлиховом опробовании уделялось отложениям аптского и альбского возрастов. Рассматриваемая территория расположена в пределах Центрального федерального округа Российской Федерации (Воронежская область - 66 \%, Курская область - $29 \%$, Липецкая область $4 \%$, Белгородская область - $1 \%$ территории листа). В геологическом строении изучаемой площади принимают участие образования кристаллического фундамента и фанерозойского осадочного чехла: девон- ские, юрские, меловые, палеогеновые, неогеновые и четвертичные отложения. Породы кайнозойской эратемы, меловой системы, а также образования верхнего девона (франский ярус) выходят на дневную поверхность.

По рассматриваемой территории проведены шлиховые маршруты, в ходе которых было изучено 24 разреза, отобрано 34 пробы (рис. 1). Девонский промежуточный коллектор имеет неблагоприятное для опробования фациальное строение - сложен глинами и известняками. Из образований аптского яруса отобрано 16 проб, из альбских псаммитов - 11, 4 пробы из песков сеноманского возраста, 1 - из берекских (палеогеновая и неогеновая системы) и 2 - из отложений усманской серии (неогеновая система). Начальный объем шлиховой пробы составил 20 литров $(0,02$ $\mathrm{M}^{3}$ ). Промывка проб проводилась на лотке сибирского типа в три стадии: отмучивание пробы, смыв легких частиц и доводка шлиха.

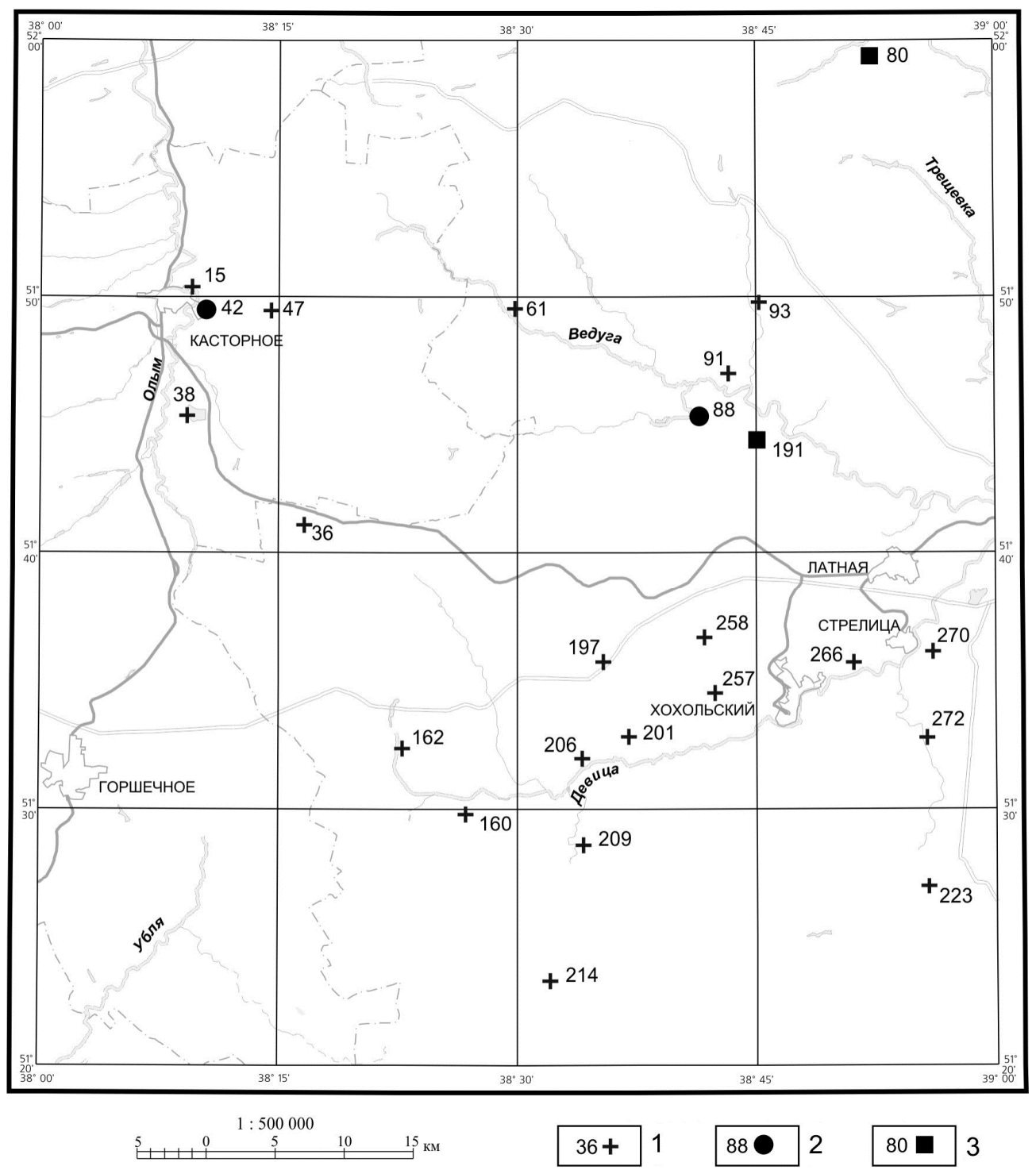

Puc. 1. Карта фактического материала: 1 - места отбора шлиховых проб; 2 - находки МИК, 3 - разрезы, содержащие повышенное количество МИК. 
Перед проведением минералогического анализа была проведена расситовка на классы крупности $+1,0$ мм, $-1,0+0,25$ мм, $-0,25+0,1$ мм и $-0,1$ мм, деление материала в тяжелой жидкости с плотностью 2,9 г/см ${ }^{3}$, фракционирование тяжелой фракции проб на магнитную, электромагнитную и немагнитную составляющие. Исходный вес проб изменяется в широких пределах: от 88,62 г до 1023,14 г, вес тяжелой фракции варьирует от 0,03 г до 21,82 г.

В составе тяжелой фракции шлиховых проб доминирующую роль играют (в \%): ильменит $(34,2-81,3)$, циркон $(1,1-35,6)$, ставролит $(0,5-21,1)$, лейкоксен $(1,8-36,7)$ и рутил $(2,2-12,7)$. В подчиненном количестве отмечаются (в \%): гидроксиды железа (до 9,7), турмалин (до 3,2), гранаты (до 14,7), дистен $(0,4$ 13,9 ), эпидот (до 2,1) и силлиманит (до 1,2 ). В качестве единичных знаков встречены: сфен, шпинель, пирит, халькопирит и хромшпинелиды.

Минералы-индикаторы кимберлитов выделены только в песках аптского возраста, всего обнаружено 4 местонахождения (рис. 1). В 2 разрезах, сложенных разнозернистыми песками криушанской свиты (т.н. 42 и 88) выделены единичные зерна хромшпинелидов, представленные плоскогранными октаэдрами.

В местонахождении Лебяжье (т.н. 80) отобрано три пробы из отложений криушанской свиты. Разрез в месте опробования представлен песками от светло-серых с желтоватым оттенком до желтых и охристо-ржавобурых, мелкозернистыми, хорошо отсортированными, кварцевыми, слабоглинистыми, с тонкой горизонтальной, пологоволнистой и наклонной слоистостью. В верхней части разреза полого-наклонные серии образуют горизонтальные пачки мощностью до 10-15 см. В песке отмечаются прослои обогащенные средне- крупнозернистым песком, из них и отобраны три шлиховые пробы - 80/301, 80/302 и 80/401. В шлиховой пробе 80/401 выделено 1784 зерен хромшпинелидов.

Тяжелая фракция из этих трех проб представлена зернами класса крупности 0,1-0,25 мм, степень окатанности соответствует 2-3 классу, отдельный зерна имеют острые ребра и вершины и относятся к 1 классу. Преобладающими минералами являются (в \%): ильменит $(50,3-76,5)$, лейкоксен $(2,9-16,3)$, ставролит $(6,9-10,5)$, циркон $(6,1-8,4)$, дистен $(2,9-5,2)$ и рутил $(3,7-4,5)$.

Выделенные зерна хромшпинелидов по особенностям морфологии и типу поверхности зерен можно разделить на несколько групп (рис. 2). К первой группе относятся правильные кристаллы октаэдрического облика с хорошо выраженными гранями и острыми или слегка сглаженными ребрами и вершинами. Поверхность зерен чаще всего матированная, реже гладкая блестящая. На отдельных гранях отмечаются углубления треугольной и прямоугольной формы. Кристаллы, как правило, имеют правильные очертания, единичные зерна искажены.

Вторая группа объединяет октаэдры со сглаженными ребрами и вершинами. Тип поверхности граней преимущественно шероховатый или матированный.
На некоторых зернах наблюдаются многочисленные каналы травления. Реже на гранях отмечаются углубления правильных геометрических очертаний, среди которых преобладают треугольники.

Среди второй группы выделено довольно много искаженных кристаллов. Отмечаются уплощенные и удлиненные зерна, разрастания граней и другие деформации. На отдельных кристаллах образуются грани ромбододекаэдра в виде полосок на ребрах октаэдра. Встречены единичные сростки хромшпинелидов.

К третьей группе относятся октаэдрические кристаллы, вершины и ребра которых притуплены мелкими гранями - вициналями. Наблюдается разная степень развития дополнительных граней, на одних зернах отмечаются только слегка сглаженные ребра и вершины, на других - многочисленные вицинали, а сами хромшпинелиды начинают приобретать округлую форму.

Кристаллы мироэдрического облика отнесены к четвертой группе. На поверхности этих зерен наблюдаются многочисленные вицинальные поверхности, за счет чего теряются грани октаэдра. Пятая группа представлена хромшпинелидами неопределимой формы, она включает обломки кристаллов и сильно корродированные зерна.

В абсолютном отношении в рассматриваемом местонахождении преобладают зерна второй группы, реже встречаются третья и первая, четвертая и пятая представлена единичными зернами.

В местонахождении Гремячий Колодезь (т.н. 191) образцы отобраны из песков криушанской свиты (нижняя часть аптского яруса). Криушанская свита в данном разрезе представлена песками от светло-серых до ржаво-желтых, разнозернистыми, преимущественно средне- мелкозернистыми. В песках наблюдается тонкая косая слоистость, объединенная в горизонтальные серии. Из местонахождения отобраны три шлиховые пробы, хромшпинелиды выделены из образца 191/401, приуроченного к нижней части разреза, всего обнаружено 763 зерна.

Содержание акцессорных минералов в изученных пробах составляет (в \%): ильменит $(48,8-55,4)$, лейкоксен $(3,9-6,8)$, циркон $(31,6-35,6)$, рутил $(2,2-3,7)$, ставролит $(0,5-3,2)$, дистен $(0,2-1,2)$.

Хромшпинелиды преимушественно сконцентрированы в размерности 0,2-0,25 мм, представлены зернами октаэдрического габитуса (рис. 3). Они имеют, как правило, матированные или шероховатые грани, на которых отмечаются каналы травления, ребра и вершины преимущественно сглажены. Наблюдаются редкие зерна с острыми ребрами и вершинами, искаженные кристаллы и хромшпинелиды с вициналями.

Хромшпинелиды обладают способностью к широкому изоморфизму входящих в их состав элементов, они кристаллизуются в довольно широком диапазоне давлений и температуры и характерны для различных по составу и происхождению пород [12]. Вариации химического состава хромшпинелидов из кимберлитов и лампроитов довольно велики, содержание основных элементов составляет (мас. \%): $\mathrm{Al}_{2} \mathrm{O}_{3}-1-58$, 

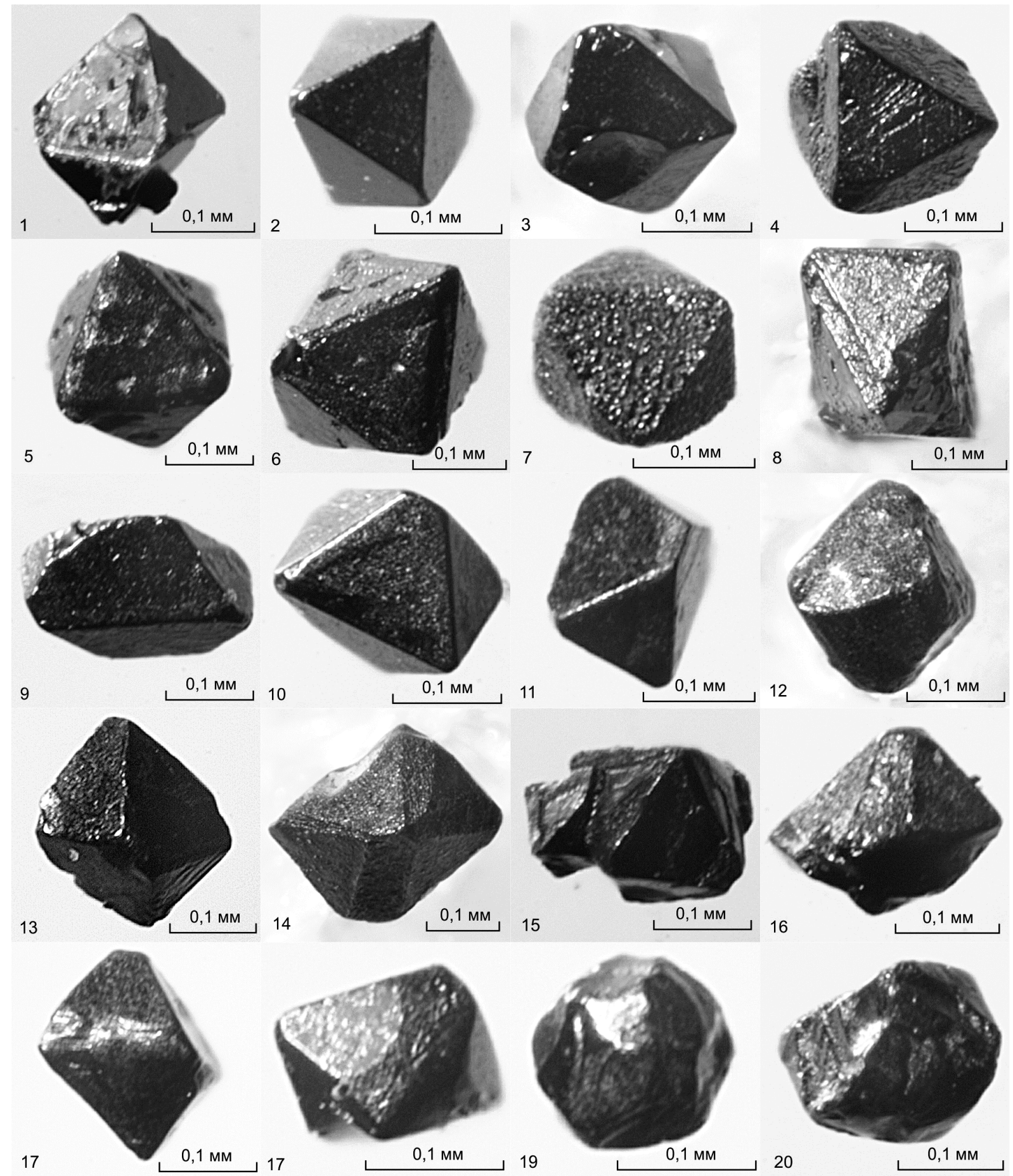

Puc. 2. Морфологические особенности хромшпинелидов (т.н. 80): 1-3 - кристаллы октаэдрического облика с хорошо выраженными гранями и острыми или слегка сглаженными ребрами и вершинами; 4-7 - октаэдры со сглаженными ребрами и вершинами; 8-13 - искаженные кристаллы; 14 - октаэдр с гранями ромбододекаэдра; 15 - сростки хромшпинелидов; 16-18 - октаэдрические кристаллы с вициналями; 19 - зерно мироэдрического облика; 20 - обломок кристалла.

$\mathrm{Cr}_{2} \mathrm{O}_{3}-4-69, \mathrm{TiO}_{2}-0,1-14, \mathrm{FeO}-10-26, \mathrm{MgO}-6-$ 28 [5]. Для хромшпинелидов алмазной ассоциации (включения хромшпинелидов в алмазах) характерны высокие содержания $\mathrm{Cr}_{2} \mathrm{O}_{3}$ - более 62 мас. \%, и низкие значения $\mathrm{Al}_{2} \mathrm{O}_{3}$ (менее 8,5 мас. \%) и $\mathrm{TiO}_{2}$ (менее 0,5 мас. \%). Доля таких алмазов в высокоалмазоносных кимберлитовых трубках, имеющих промышленное значение, составляет около 16-28 \% [4, 13].
Для изучения химического состава хромшпинелидов было исследовано 115 зерен, 83 из местонахождения Лебяжье и 32 из разреза Гремячий Колодезь. Содержание основных компонентов определялось на электронном микроскопе Jeol 6380 LV с энергодисперсионной системой количественного анализа Inca250 (ВГУ, аналитик Н. С. Базиков).

Изученные хромшпинелиды отмечаются широкой 


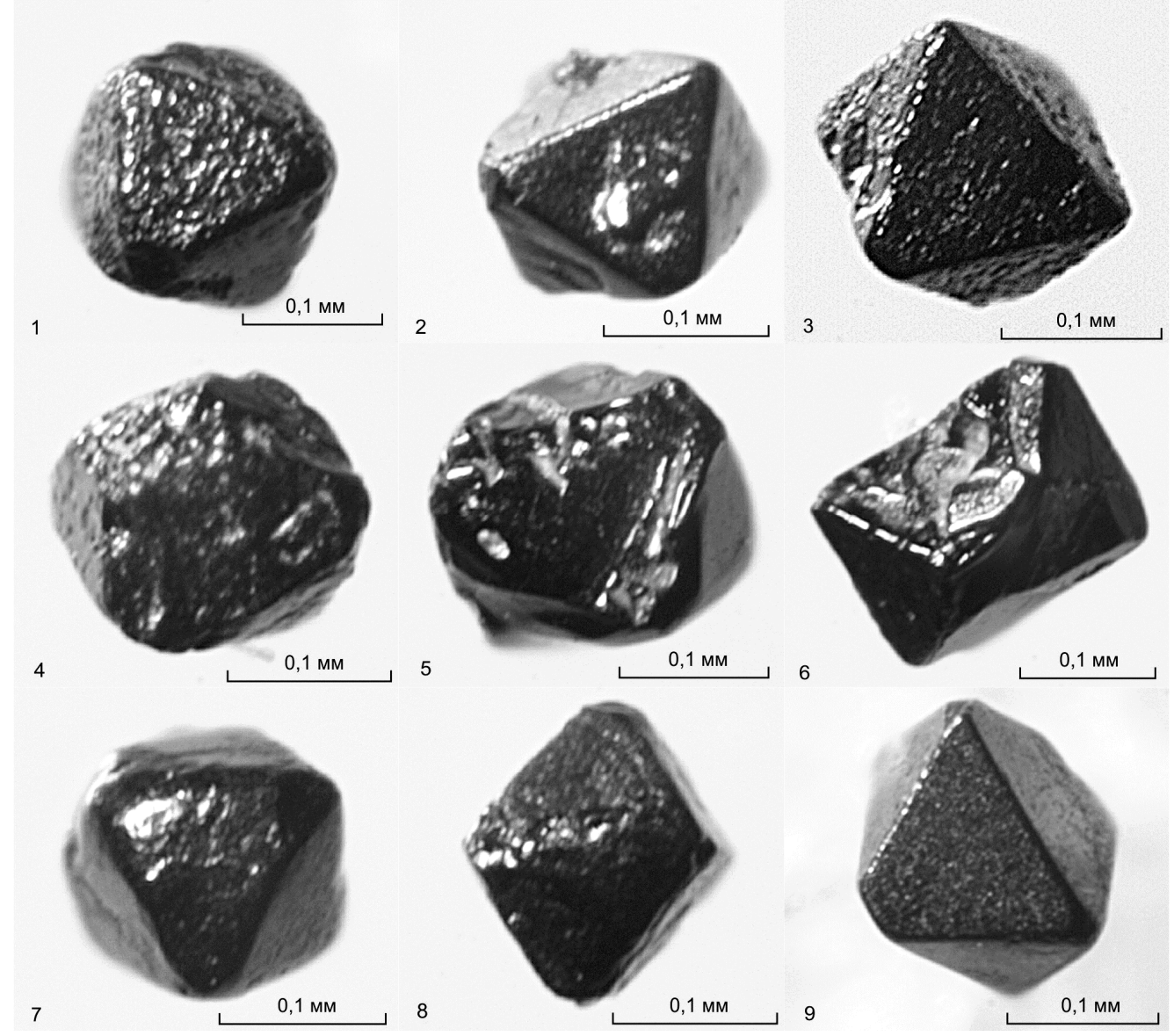

Puc. 3. Морфологические особенности хромшпинелидов (т.н. 191): 1-4 - октаэдры со сглаженными ребрами и вершинами; 5-6 - искаженные кристаллы; 7-8 - октаэдрические кристаллы с вициналями; 19 - хромшпинелид с слегка сглаженными ребрами и вершинами.

вариацией входящих в их состав элементов. В местонахождении Лебяжье содержания составляют (мас. $\%): \mathrm{TiO}_{2}$ до 5,05, $\mathrm{Al}_{2} \mathrm{O}_{3}-3,89-39,86, \mathrm{MgO}$ до 17,5 , $\mathrm{Cr}_{2} \mathrm{O}_{3}-25,59-70,42, \mathrm{FeO}-11,16-47,03$. Для разреза Гремячий Колодезь характерны более узкие интервалы химических составов (мас. \%): $\mathrm{TiO}_{2}$ до 7,35, $\mathrm{Al}_{2} \mathrm{O}_{3}$ - 4,16-33,44, MgO - 4,89-17,0, $\mathrm{Cr}_{2} \mathrm{O}_{3}$ - 32,76-68,13, $\mathrm{FeO}-13,92-37,98$.

Для генетической интерпретации изученных хромшпинелидов использованы диаграммы составов минералов, сама разбраковка основана на выделении полей составов и полученных трендов [14-16].

На диаграмме Н.В. Соболева [14] области составов хромшпинелидов показаны в координатах $\mathrm{Cr}_{2} \mathrm{O}_{3}-$ $\mathrm{Al}_{2} \mathrm{O}_{3}$ и $\mathrm{Cr}_{2} \mathrm{O}_{3}-\mathrm{TiO}_{2}$ (рис. 4). Для пород кимберлитовой серии характерно наличие двух трендов: перидотитового (в виде полосы вдоль линии постоянного содержания железа) и пикритового (в виде полосы или облака вдоль оси $\left.\mathrm{Cr}_{2} \mathrm{O}_{3}\right)$ [6].

Для зерен из разреза Гремячий Колодезь наблюдается плохо выраженный двойной - перидотитовый и пикритовый тренд. В область алмазной ассоциации попадают 5 знаков. Для местонахождения Лебяжье наблюдается хорошо выраженный перидотитовый тренд. Точки составов зерен группируются вдоль оси хромит-алюмохромит-хромпикотит. Пикритовый
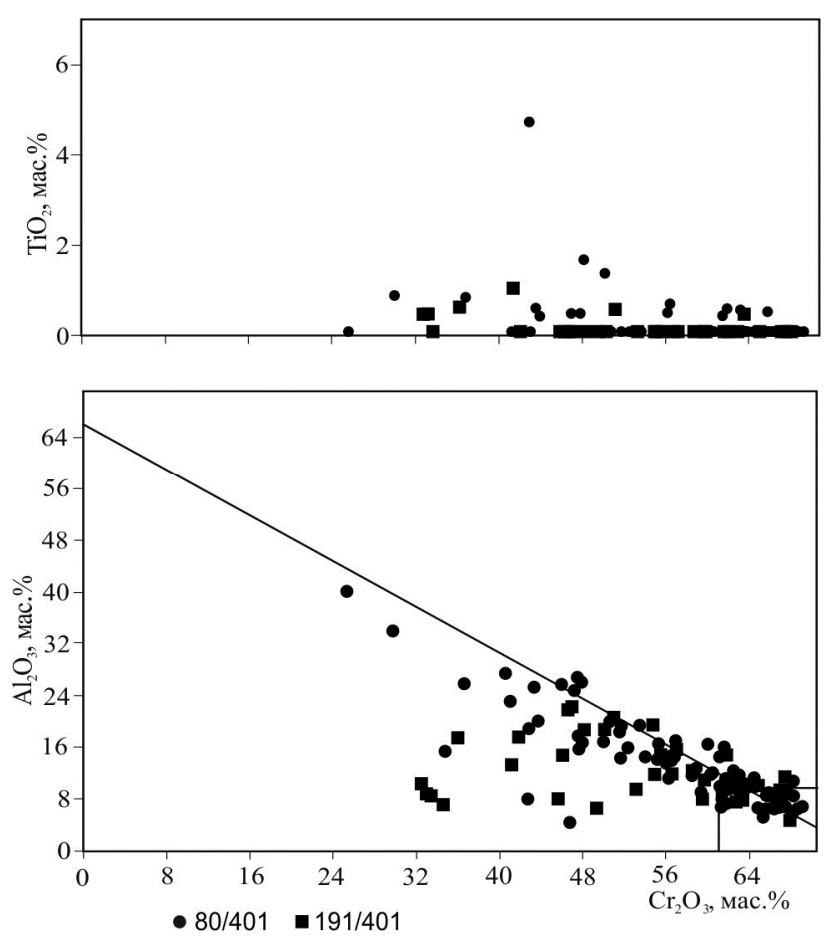

Puc. 4. Особенности состава хромшпинелидов в координатах $\mathrm{TiO}_{2}-\mathrm{Cr}_{2} \mathrm{O}_{3}$ и $\mathrm{Al}_{2} \mathrm{O}_{3}-\mathrm{Cr}_{2} \mathrm{O}_{3}$ (диаграмма Н. В. Соболева). 
тренд не характерен, только единичные зерна группируются по оси хрома. Отдельно обособляются зерна с повышенным содержанием $\mathrm{TiO}_{2}$. Около $32 \%$ проанализированных хромшпинелидов характеризуется высоким содержанием $\mathrm{Cr}_{2} \mathrm{O}_{3}$ и низким $\mathrm{Al}_{2} \mathrm{O}_{3}$ и попадает в поле составов алмазной ассоциации.

На диаграмме Ч. Фипке [15] в координатах $\mathrm{MgO}-$ $\mathrm{Cr}_{2} \mathrm{O}_{3}$ для большинства точек составов наблюдается отрицательная корреляция $\mathrm{Cr}$ и $\mathrm{Mg}$ (перидотитовый тренд), свойственный высокоалмазоносным кимберлитам и лампроитам (рис. 5). Для части составов характерен параболический тренд (сочетание перидотитового и пикритового). Данный тренд характерен для слабоалмазоносных пород. Из разреза Гремячий Колодезь 2 точки составов попадают в поле включений в
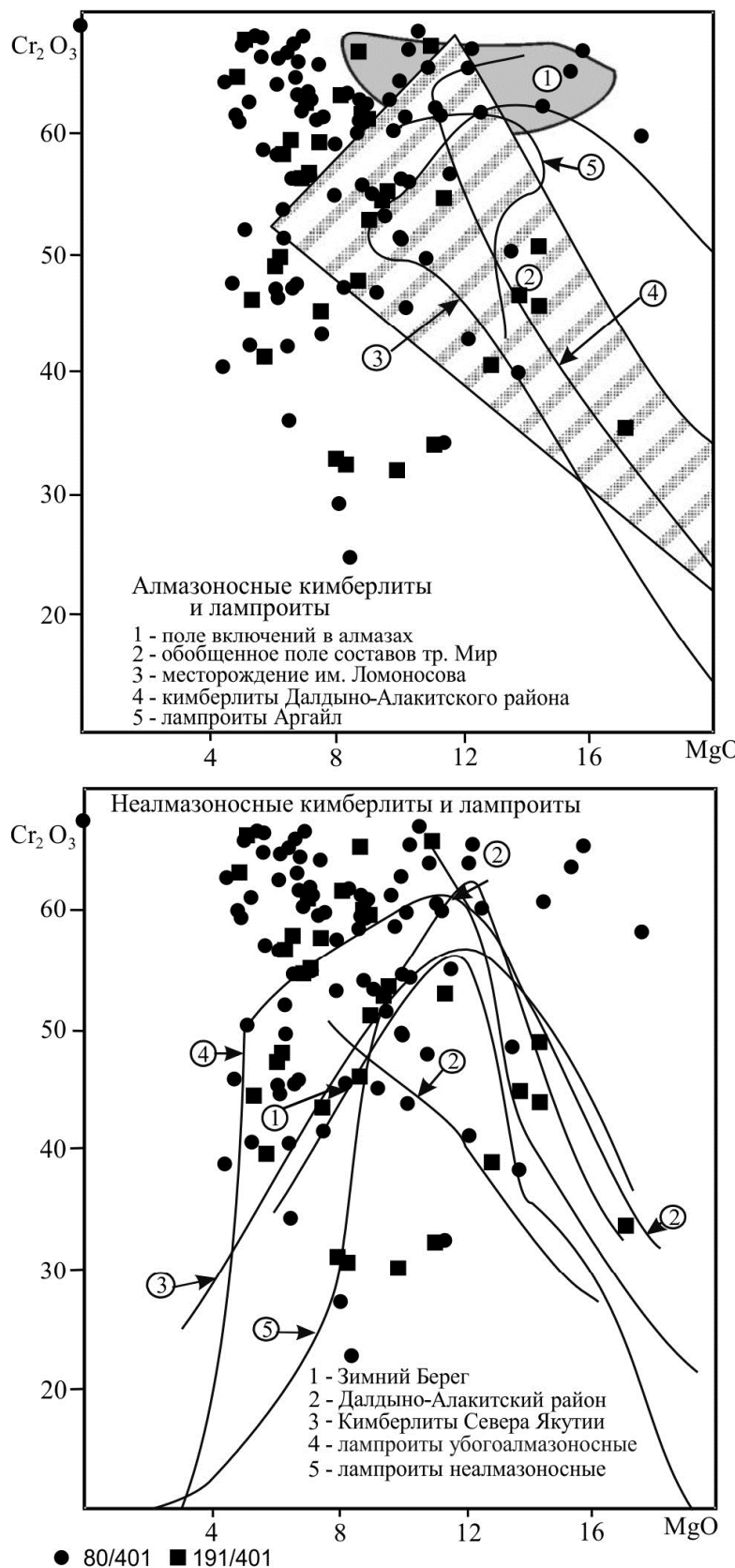

алмазах, из местонахождения Лебяжье в это же поле попадает 11 точек.

По своему химическому составу хромшпинелиды из местонахождения Лебяжье близки зернам «курунгского» типа. Данный тип хромшпинелидов впервые был выделен в верхнепалеозойских отложениях Малоботуобинского района Якутии [5]. Для них характерна повышенная хромистость и низкое содержание $\mathrm{Al}_{2} \mathrm{O}_{3}$ и $\mathrm{TiO}_{2}$, а на диаграмме Н.В. Соболева отмечается хорошо выраженный перидотитовый тренд. Предполагалось, что данные зерна поступали в разрез из неизвестных кимберлитовых тел. Впоследствии было доказано, что хромшпинелиды «курунгского» типа не связаны с кимберлитами, а их источником являются ультраосновные массивы [5, 17].
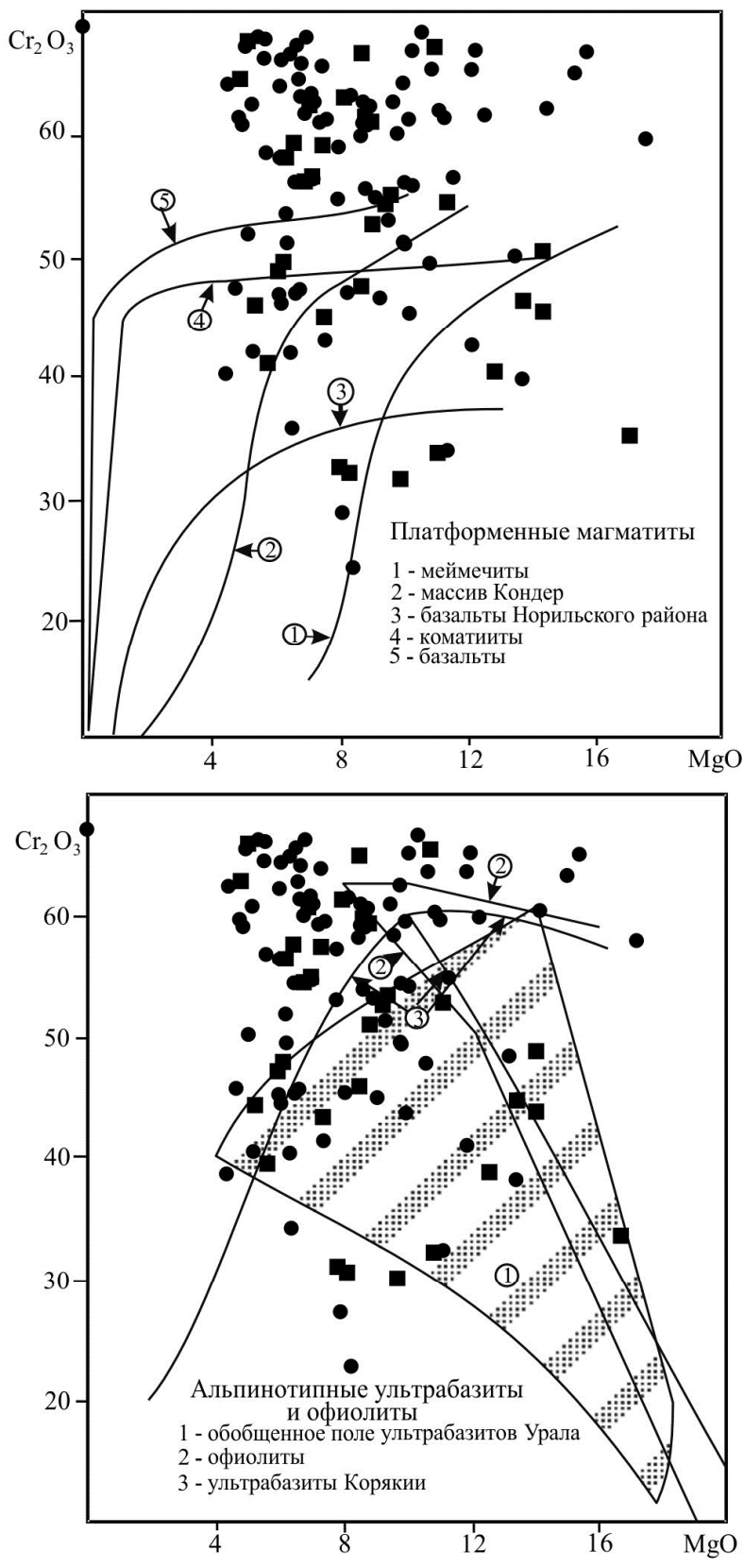

Puc. 5. Особенности состава хромшпинелидов в координатах $\mathrm{MgO}-\mathrm{Cr}_{2} \mathrm{O}_{3}$ (диаграмма Ч. Фипке). 
Выделенные из местонахождения Лебяжье хромшпинелиды, несмотря на сходство химического состава, существенно отличаются от «курунгских» по своей морфологии. Для кристаллов «курунгского» типа характерны острореберные и островершинные октаэдры с продольной штриховкой. Искаженные октаэдры нехарактерны, полностью отсутствуют зерна мироэдрического облика и вицинали, притупляющие ребра и вершины кристаллов.

Пикроильменит является нехарактерным минералом, встречен в изученных местонахождениях в количестве нескольких десятков знаков. Зерна имеют овальную и лепешковидную форму с кавернозной поверхностью. По своему химическому составу пикроильменит низкомагнезиальный ( $\mathrm{MgO}$ не более 5,13 мас. \%) и не связан с кимберлитами и лампроитами.

Осадконакопление в аптское время на большей части рассматриваемой территории происходило в континентальных условиях (криушанская, девицкая и волчинская свиты). Только на крайнем северо-западе распространена зушская толща, которая формировалась в морских условиях. Наличие в разрезе континентальных отложений позволяет достаточно точно установить направление сноса, который в аптский век происходил с юго-востока на северо-запад.

Таким образом, предполагаемый коренной источник МИК расположен юго-восточнее изученной площади, в пределах Лосевской шовной зоны, имеющей возраст архей-ранний протерозой. Исходя из тектонической позиции, коренным источником индикаторных минералов, по-видимому, являются лампроиты.

\section{Выводы}

Аптский промежуточный коллектор на северном склоне Воронежской антеклизы содержит рекордное количество минералов-индикаторов кимберлитов. Количество выделенных хромшпинелидов на рассмотренной территории достигает 1784 знака на пробу объемом 20 литров.

Выделенные хромшпинелиды характеризуются повышенным содержанием $\mathrm{Cr}_{2} \mathrm{O}_{3}$. В разрезе Лебяжье около $32 \%$ проанализированных зерен на диаграмме Н. В. Соболева попадают в область алмазной ассоциации. Такое соотношение характерно для высокоалмазоносных кимберлитовых тел. На диаграмме Ч. Фипке в поле включений в алмазах попадает 11 точек.

По химическому составу изученные хромшпинелиды близки зернам «курунгского» типа, однако существенно отличаются от них по морфологии. В местонахождении Лебяжье выделены хромшпинелиды «мантийного» типа, представленные мироэдрическими кристаллами и октаэдрами с винициальными гранями.

Находки МИК в континентальных отложениях позволяют довольно точно установить направление сноса, который происходил в это время с юго-востока на северо-запад.
Источником индикаторных минералов, повидимому, являются лампроиты. Данное предположение подтверждается несколькими фактами. В лампроитах количество пиропов и пикроильменитов снижено, а хромшпинелидов повышено [16, 18]. Именно такой набор МИК наблюдается в изученных местонахождениях - многочисленные зерна хромшпинелидов (в том числе принадлежащие алмазной ассоциации) при отсутствии высокомагнезиальных пикроильменитов и пиропов. Предполагаемого источника сноса расположен в пределах Лосевской шовной зоны AR$\mathrm{PR}_{1}$ возраста. Севернее рассматриваемой территории, в аптских образованиях, имеются находки алмазов, в том числе, мелкого алмаза красного цвета характерного для лампроитов Австралии [7, 9].

\section{ЛИТЕРАТУРА}

1. Геология, прогнозирование, методика поисков, оценки и разведки месторождений алмазов. Книга 2. Россыпные месторождения / В. Е. Минорин [и др.] - Якутск. - 2004. $424 \mathrm{c}$.

2. Геология промежуточных коллекторов алмазов / А.А. Немиров [и др.] - Новосибирск: Наука. - 1994. - 136 с.

3. Харькив, А.Д. Геолого-генетические основы шлихоминералогического метода поисков алмазных месторождений. / А. Д. Харькив, Н. Н. Зинчук, А. И. Крючков. - М.: Недра. - 1995. - 348 с.

4. Хмельков, А. М. Основные минералы кимберлитов и их эволюция в процессе ореолообразования (на примере Якутской алмазоносной провинции) / А. М. Хмельков. - Новосибирск: АРТА. - 2008. - 252 с.

5. Афанасьев, В. П. Морфология и морфогенез индикаторных минералов кимберлитов. / В.П. Афанасьев, Н.Н. Зинчук, Н. П. Похиленко. - Новосибирск. - 2001. - 276 с.

6. Харькив, А. Д. Минералогические основы поисков алмазных месторождений / А. Д. Харькив. - М.: Недра. - 1978. $136 \mathrm{c}$.

7. Савко, А. Д. Алмазоносность Воронежской антеклизы / А. Д. Савко, Н. Н. Зинчук, Л. Т. Шевырев // Тр. науч.-исслед. ин-та геологии Воронеж. гос. ун-та. - Вып. 17. - Воронеж, ВГУ. - 2003. - 120 с.

8. Черешинский, А. В. Акцессорные минералы базальных горизонтов Воронежской антеклизы (в связи с вопросами алмазоносности) / А. В. Черешинский, А. Д. Савко // Тр. науч.-исслед. ин-та геологии Воронеж. гос. ун-та. - Вып. 48. - Воронеж: Изд-во ВГУ. - 2007. - 120 с.

9. Шевырев, Л. Т. Алмазоносность центральной части Восточно-Европейской платформы (Воронежская антеклиза) / Л. Т. Шевырев, А. В. Черешинский // Тр. науч.-исслед. ин-та геологии Воронеж. гос. ун-та. - Вып. 90. - Воронеж: Изд-во ВГУ. - 2015. - $283 \mathrm{c}$.

10. Черешинский, А. В. Минералы-индикаторы кимберлитов Мезозойского промежуточного коллектора Воронежской антеклизы / А. В. Черешинский // Вестн. Воронеж. гос. унта. Сер.: Геология. - 2017. - № 2. - С. 107-114.

11. Савко, А. Д. Алмазы и их спутники из осадочного чехла воронежской Антеклизы / А. Д. Савко, Л. Т. Шевырев, В. В. Ильяш // Тр. науч.-исслед. ин-та геологии Воронеж. гос. унта. - Вып. 47. - Воронеж, ВГУ. - 2007. - 122 с.

12. Плаксенко, $A$. Н. Типоморфизм акцессорных хромшпинелидов ультрамафит-мафитовых магматических формаций / А. Н. Плаксенко. - Воронеж: Изд-во Воронеж. ун-та, 1989. $-221 \mathrm{c}$. 
13. Харькив, А. Д. Коренные месторождения алмазов мира / А. Д. Харькив, Н. Н. Зинчук, А. И. Крючков. - М. - 1998. $555 \mathrm{c}$.

14. Соболев Н. В. О минералогических критериях алмазоносности / Н. В. Соболев // Геология и геофизика. - 1971. № $1 .-$ C. 70-80.

15. Fipke, C. E. Significance of chromite, ilmenite, G5 Mgalmandine garnet, zircon and tourmaline in heavy mineral detection of diamond bearing lamproite / C. E. Fipke // V International Kimberlite Conference, Brazil. Spec. Publ. 1A. - 1994. - C. 366-381.

НИИ Геологии Воронежского госуниверситета

Черешинский Алексей Васильевич, ответственный исполнитель, кандидат геолого-минералогических наук

E-mail:vsu31022@mail.ru

Тел.: 8 (473) 220-78-42
16. Ваганов, В. И. Алмазные месторождения России и мира (основы прогнозирования) / В. И. Ваганов. - М.: ЗАО «Геоинформмарк». $-2000 .-371 \mathrm{c}$.

17. Особенности морфологии и состава некоторых хромшпинелидов алмазоносных площадей в связи с проблемой «ложных» индикаторов кимберлитов / В. П. Афанасьев [и др.] // Геология и геофизика. - т. 41. - № 12. - С. 1729-1741. 18. Лапин, А. В. Кимберлиты и некимберлитовая алмазоносность изверженных и метаморфических пород / А. В. Лапин, Г. С. Гусев. - М.: ГЕОКАРТ. - 2010. -448 с.

Research Institute of Geology of the Voronezh State University Chereshinskii A. V., Responsible Contractor, Candidate of Geological and Mineralogical Sciences

E-mail:vsu31022@mail.ru

Tel.: 8 (473) 220-78-42 